\title{
IDENTIFICATION AND CHARACTERIZATION OF POTENTIAL PHENOL DEGRADING BACTERIAL STRAINS ISOLATED FROM MUNICIPAL SEWAGE, BILASPUR, CHHATTISGARH
}

\author{
Rashmi Parihar and Sumit Kumar Dubey* \\ Department of Microbiology, Government E. Raghvendra Rao PG. Science College, Bilaspur, India \\ *Corresponding author's email: sumitdubey4444@ gmail.com
}

\begin{abstract}
Phenol and its derivatives are consistently causing harmful effects to an aquatic ecosystem. The present study focused on the isolation and characterization of potential phenol degrading bacterial strains and subsequently optimization of media ingredients for efficient phenol degradation by potential bacterial strains. Bacterial strains were isolated from municipal sewage, Bilaspur (21'47 and 23'8 N 81'14 and 83'15 E). After optimization phenol degradation rate was increased by 1.84 fold for PDB 5 (from 40.37\% to 74.67\%) and 1.39 fold for PDB 11 (from $58.62 \%$ to $81.51 \%$ ) at 500mg/l initial phenol concentration. PDB 5 and PDB 11 were identified as Streptococcus sp. PDB 5 and Pseudomonas $s p$. PDB 11 respectively as potential phenol degrading bacterial strains. These strains can further be used in microbially assisted phenol degradation to remove phenol derivatives present in industrial wastewater.
\end{abstract}

Keywords: Phenol; Aquatic ecosystem; Microbially assisted phenol degradation; Optimization; Municipal sewage; Streptococcus sp. PDB 5; Pseudomonas sp. PDB 11

\section{Introduction}

Effluents of Petrochemical, coke oven, dye industries, plastic and fiberglass manufacturing unit, pulp and paper production, herbicide manufacturing and oil refineries have been reported for higher amount of phenolic compounds (Paisio et al., 2013, Mohite et al., 2010, El-Ashtoukhy et al., 2013, Veeresh et al., 2005, Jadhav and Vanjara, 2004). These phenolic compounds enter into aquatic food chain when untreated or by improper treated industrial wastewater drained into natural water reservoirs e.g. ponds, lakes, rivers, and oceans. Further phenolic compounds cause harm to aquatic living organisms (e.g. fish) and related organisms which depend on them as a food source (e.g. Eagle and humans). WHO quoted that short-term exposure of excess phenol inside human body causes liver and kidney damage, harmful effects on respiratory system and growth retardation.

Physical methods (such as ultraviolet rays, ozonation), chemical methods (e.g. hydrogen peroxide and Fenton's reaction) and its combination (physio-chemical methods) have been applied to remove phenolic compounds from industrial wastewater (Lin et al., 1994; Zilli et al., 1993). Presently the chemical treatments have been used in most of the industrial wastewater treatments. But it has been found to produce harmful secondary pollutants and costly as well (Agarry et al., 2008). The biological degradation of phenolic compounds is an alternative approach to overcome aforementioned issues. It is an eco-friendly and costeffective method to remove excess phenolic compounds from the industrial wastewater. The pure or mixed cultures of microorganisms which are able to utilize phenolic compounds as an energy source can be used for biological degradation of phenols (Allsop et al., 1993; Wang et al., 1999; Yuan et al. 2000; Sa et al, 2001). Diverse microorganisms like bacteria, yeasts, algae and filamentous fungi have been reported for their metabolic capability to degrade phenol at high concentrations (Sivasubramanian and Namasivayam, 2014).

Microorganisms can metabolize phenolic compounds by either ortho- or meta-cleavage (Dagley, 1971; Agarry et al., 2008). Phenol hydroxylase has known as the first enzyme in both metabolic pathways (ortho- or meta-pathway). The final products of both ortho- and meta-pathways are entering into the Tricarboxylic acid cycle (TCA) for complete mineralization (Shingler, 1996). 
The present study is focused on the isolation and characterization of phenol-degrading bacteria from municipal sewage, Bilaspur and optimization of different parameters to enhance the rate of phenol degradation by potential bacterial isolates.

\section{Materials and Methods}

\section{Sampling}

Samples were collected from Municipal sewage water, Bilaspur (21'47 and 23'8 N latitudes and 81'14 and 83'15 E latitudes) for the isolation of Phenol degrading bacterial strains and stored in sterile plastic containers at $4^{\circ} \mathrm{C}$ until used.

\section{Isolation}

Serial dilution method was adopted for isolation of bacterial strains. Serially diluted samples were inoculated in Nutrient Agar Media (NAM) plates and incubated at $37^{\circ} \mathrm{C}$ for $24 \mathrm{~h}$. These NAM plates served as master plates for the isolation of phenol degrading bacterial strains. After incubation, the pure cultures of bacteria were prepared by streak plate method.

\section{Acclimatization of Bacterial Strains}

Pure cultures of bacteria were acclimatized for one month in mineral salt medium (MSM) containing phenol as the sole carbon source at a concentration of $500 \mathrm{mg} / 1$ at $37^{\circ} \mathrm{C}$ and $140 \mathrm{rpm}$. MSM consisted of $(\mathrm{g} / \mathrm{l})\left(\mathrm{NH}_{4}\right)_{2} \mathrm{SO}_{4}-0.2$, $\mathrm{CaCl}_{2}-0.007, \mathrm{FeCl}_{3}-0.001, \mathrm{MnSO}_{4} \mathrm{H}_{2} \mathrm{O}-0.1, \mathrm{MgSO}_{4} 7 \mathrm{H}_{2} \mathrm{O}-$ 1.0, $\mathrm{K}_{2} \mathrm{HPO}_{4}-0.50, \mathrm{KH}_{2} \mathrm{PO}_{4}-0.25$ and glucose-2.0 (pH 7.0).

\section{Phenol Degradation}

The ability of the acclimatized bacterial strains to degrade phenol was determined. Experiments were carried out in $150 \mathrm{ml}$ Erlenmeyer flask containing $50 \mathrm{ml}$ of MSM with phenol concentration at $500 \mathrm{mg} / 1$. A loop full bacterial culture (McFarland Standard-0.5; $1.5 \times 10^{8}$ cells) was aseptically inoculated in the flasks containing sterilized MSM and incubated at $37^{\circ} \mathrm{C}$ in the shaker $(150 \mathrm{rpm})$. Samples were withdrawn at every $24 \mathrm{~h}$ time interval (till the completion of incubation period), centrifuged and analyzed for phenol concentration for the assessment of the rate of phenol degradation by respective bacterial strains. Initial phenol concentration was subtracted by residual phenol concentration (concentration of phenol remained after the microbial phenol degradation) for the assessment of phenol degrading efficiency of microbial strains. Percentage phenol degradation $(\mathrm{g} / \mathrm{l})$ was calculated as per formula is shown below:

Percentage phenol degradation $\left(\% P_{D}\right)$ $=\frac{\text { Initial phenol concentration }- \text { Residual phenol concentration }}{}$

$\times 100$

Initial phenol concentration - initial amount (mg/l) of phenol

Residual phenol concentration- amount $(\mathrm{mg} / \mathrm{l})$ of phenol remained after biodegradation

\section{Phenol Estimation Assay}

Phenol concentration was determined quantitatively by a colorimetric method by using 4-aminoantipyrine (4- AAP) as the chromophore. Protocol was adopted from Standard Methods for the Examination of Water and Wastewater (Greenberg et al., 1992) with some modification. Reaction mixture consisted of $0.9 \mathrm{ml}$ double distilled water, $0.1 \mathrm{ml}$ supernatant (sample), $50 \mu \mathrm{l}$ of $2 \mathrm{~N} \mathrm{NH}_{4} \mathrm{OH}$ (pH-10.0), $25 \mu \mathrm{l}$ of $2 \%$ 4- AAP and $25 \mu 18 \%$ of $\mathrm{K}_{3} \mathrm{Fe}(\mathrm{CN})_{6}$ at $40^{\circ} \mathrm{C}$. Optical density was measured at $510 \mathrm{~nm}$.

\section{Estimation of Cell Biomass Concentration}

Cell biomass concentration was estimated in terms of $\mathrm{CFU} / \mathrm{ml}$ as per standard method.

\section{Morphological and Biochemical Characterization}

Morphological, Physiological and Biochemical characterization (as per described in Bergey's Manual) were done for the identification of potential phenol degrading bacterial isolates.

\section{Results}

\section{Isolation}

Total sixteen bacterial strains (PDB 1, PDB 2, PDB 3, PDB 4, PDB 5, PDB 6, PDB 7, PDB 8, PDB 9, PDB 10, PDB 11, PDB 12, PDB 13, PDB 14, PDB 15 and PDB 16) were isolated from municipal sewage (Table 1). PDB 3, PDB 4, PDB 5, PDB 6, PDB 7, PDB 8, PDB 9, PDB 10, PDB 11, PDB 14 and PDB 15 showed more than $10 \%$ of phenol degradation.

Table 1: Percentage phenol degradation rate by bacterial isolates

\begin{tabular}{|c|c|c|}
\hline S.N. & Bacterial isolate & PD ( \pm SD $) \%$ \\
\hline 1 & PDB 1 & $*$ \\
\hline 2 & PDB 2 & $*$ \\
\hline 3 & PDB 3 & $14.75( \pm 1.29)$ \\
\hline 4 & PDB 4 & $20.41( \pm 0.40)$ \\
\hline 5 & PDB 5 & $40.37( \pm 0.27)$ \\
\hline 6 & PDB 6 & $32.33( \pm 0.44)$ \\
\hline 7 & PDB 7 & $27.83( \pm 0.39)$ \\
\hline 8 & PDB 8 & $19.96( \pm 0.55)$ \\
\hline 9 & PDB 9 & $13.71( \pm 0.58)$ \\
\hline 10 & PDB 10 & $35.88( \pm 0.26)$ \\
\hline 11 & PDB 11 & $58.62( \pm 1.16)$ \\
\hline 12 & PDB 12 & $*$ \\
\hline 13 & PDB 13 & $*$ \\
\hline 14 & PDB 14 & $22.30( \pm 1.10)$ \\
\hline 15 & PDB 15 & $25.44( \pm 0.45)$ \\
\hline 16 & PDB 16 & $*$ \\
\hline
\end{tabular}

PD- Phenol degradation; $* \geq 10 \%$;

Initial phenol concentration was $500 \mathrm{mg} / 1$ 


\section{Screening of Phenol Degradation}

Two bacterial strains PDB 5 and PDB 11 showed significant phenol degradation efficiency $40.37 \%$ and $58.63 \%$ respectively, after $96 \mathrm{~h}$ (Table 1).

\section{Optimization of Bacterial Strains for Maximum Phenol Degradation}

Physiochemical parameters and media composition for bacterial strain under un-optimized and optimized condition are shown in Table 2. PDB 5 and PDB 11 showed maximum phenol degradation at $35^{\circ} \mathrm{C}$ and $37^{\circ} \mathrm{C}$ respectively while $\mathrm{pH}$ 6.5 and 7.5 respectively (Table 2 ). Finally after optimization phenol degradation rate was found to increase from $40.37 \%$ to $74.67 \%$ for PDB 5 and from $58.62 \%$ to $81.51 \%$ for PDB 11 (Table 3).

\section{Morphological and Biochemical Characterization}

Morphological (Table 4) and Biochemical (Table 5) characterizations were done for the identification of bacterial isolates (PDB 5 and PDB 11). PDB 5 and PDB 11 were identified as Streptococcus sp. PDB 5 and Pseudomonas sp. PDB 11 respectively (Table 6). Percentage (\%) Similarities were calculated as per Morphological and Biochemical characteristics similarity from existing database of Streptococcus epidermis and Pseudomonas aeruginosa to bacterial isolate PDB 5 and PDB 11 respectively (Table 6).

Table 2: Un-optimized and optimized condition for bacterial isolates

\begin{tabular}{|c|c|c|c|c|}
\hline \multirow{2}{*}{ S.N. } & \multirow{2}{*}{ Parameters } & \multirow{2}{*}{ Un-optimized } & \multicolumn{2}{|c|}{ Optimized } \\
\hline & & & (PDB 5) & (PDB 11) \\
\hline 1 & $\mathrm{pH}$ & 7.0 & 6.5 & 7.5 \\
\hline 2 & Temperature $\left({ }^{\circ} \mathrm{C}\right)$ & 37 & 35 & 40 \\
\hline 3 & Time (hours) & 96 & 96 & 96 \\
\hline \multirow[t]{2}{*}{4} & Preinoculum (\%) & 1 & 5 & 5 \\
\hline & \multicolumn{4}{|l|}{ Media Composition } \\
\hline 1 & Yeast extract $(\mathrm{g} / \mathrm{l})$ & NA & 1.25 & 1.25 \\
\hline 2 & Glucose (g/l) & 2.0 & 2.0 & 2.0 \\
\hline 3 & $\left(\mathrm{NH}_{4}\right)_{2} \mathrm{SO}_{4}(\mathrm{~g} / \mathrm{l})$ & 0.2 & 0.2 & 0.2 \\
\hline 4 & $\mathrm{MnSO}_{4} \mathrm{H}_{2} \mathrm{O}(\mathrm{g} / \mathrm{l})$ & 0.1 & 0.1 & 0.1 \\
\hline 5 & $\mathrm{MgSO}_{4} 7 \mathrm{H}_{2} \mathrm{O}(\mathrm{g} / \mathrm{l})$ & 1.0 & 1.0 & 1.0 \\
\hline 6 & $\mathrm{~K}_{2} \mathrm{HPO}_{4}(\mathrm{~g} / \mathrm{l})$ & 0.5 & 0.5 & 0.5 \\
\hline 7 & $\mathrm{KH}_{2} \mathrm{PO}_{4}(\mathrm{~g} / \mathrm{l})$ & 0.25 & 0.25 & 0.25 \\
\hline 8 & $\mathrm{CaCl}_{2}(\mathrm{mg} / \mathrm{l})$ & 7.0 & 7.0 & 7.0 \\
\hline 9 & $\mathrm{FeCl}_{3}(\mathrm{mg} / \mathrm{l})$ & 1.0 & 1.0 & 1.0 \\
\hline 10 & $\mathrm{ZnSO} 4.7 \mathrm{H}_{2} \mathrm{O}(\mathrm{mg} / \mathrm{l})$ & NA & 0.1 & 0.1 \\
\hline 11 & $\mathrm{CuSO} 4.5 \mathrm{H} 2 \mathrm{O}(\mathrm{mg} / \mathrm{l})$ & NA & 0.2 & 0.2 \\
\hline 12 & $\mathrm{Na}_{2} \mathrm{Mo}(\mathrm{O}) 4(\mathrm{mg} / \mathrm{l})$ & NA & 0.1 & 0.1 \\
\hline
\end{tabular}

NA - Not added in media

Table 3: Phenol degradation rate of bacterial isolates (Un-optimized and Optimized)

\begin{tabular}{|c|c|c|c|c|c|}
\hline \multirow[b]{2}{*}{ S.N. } & \multirow{2}{*}{$\begin{array}{l}\text { Bacterial } \\
\text { isolate }\end{array}$} & \multirow{2}{*}{$\begin{array}{l}\text { Initial Phenol } \\
(\mathrm{mg} / \mathrm{l})\end{array}$} & Un-optimized & Optimized & \multirow{2}{*}{$\begin{array}{l}\text { Fold increase in } \% \text { phenol } \\
\text { degradation rate }\end{array}$} \\
\hline & & & $\begin{array}{l}\text { Phenol degradation } \\
( \pm \text { SD) } \%\end{array}$ & $\begin{array}{l}\text { Phenol degradation } \\
( \pm \text { SD) } \%\end{array}$ & \\
\hline 1 & PDB 5 & 500 & $40.37( \pm 0.27)$ & $74.67( \pm 0.39)$ & 1.84 \\
\hline 2 & PDB 11 & 500 & $58.62( \pm 1.16)$ & $81.51( \pm 0.89)$ & 1.39 \\
\hline
\end{tabular}

Initial phenol concentration-500mg/l; Time $96 \mathrm{~h} ; \mathrm{pH}$ (PDB 5; 6.5 and PDB 11; 7.5) and

Temperature (PDB $5 ; 35^{\circ} \mathrm{C}$ and PDB $11 ; 40^{\circ} \mathrm{C}$ ) 
Table 4: Morphological characteristics of bacterial isolates

\begin{tabular}{|l|l|l|l|}
\hline SN & $\begin{array}{l}\text { Morphological } \\
\text { characteristics }\end{array}$ & PDB 5 & PDB 11 \\
\hline 1 & Colony Color & $\begin{array}{l}\text { Pale } \\
\text { yellow }\end{array}$ & Cream \\
\hline 2 & Surface Texture & Smooth & Ssmooth \\
\hline 3 & Colony Elevation & Raised & Convex \\
\hline 4 & Colony Diameter & $1.2 \mathrm{~mm}$ & $1.6 \mathrm{~mm}$ \\
\hline 5 & Gram Stain & + & - \\
\hline 6 & Shape & Coccid & Rod \\
\hline 7 & Spore & $+(\mathrm{ND})$ & + \\
\hline 8 & Capsule & + & + \\
\hline
\end{tabular}

ND- No data available in database when calculating percentage similarity.

Table 5: Biochemical characteristics of bacterial isolates

\begin{tabular}{|l|l|c|c|}
\hline S.N. & Biochemical Characteristics & PDB 5 & PDB 11 \\
\hline 1 & Catalase & + & + \\
\hline 2 & Indole production & - & - \\
\hline 3 & Acid Production & + & + \\
\hline 4 & Gas Procution & + & - \\
\hline 5 & Voges-Proskauer & + & + \\
\hline 6 & Citrate utilization & + & + \\
\hline 7 & Nitrate reduction & - & $+*$ \\
\hline 8 & H2S production & + & - \\
\hline & Hydrolysis & $+($ ND) & - \\
\hline 9 & Casein & + & - \\
\hline 10 & Urea & $-($ ND) & + \\
\hline 11 & Glycerol & + & + \\
\hline 12 & Gelatin & + & - \\
\hline 14 & Lactose & + & - \\
\hline 15 & Sucrose & + & + \\
\hline 16 & Glucose & + & + \\
\hline 17 & Fructose & Maltose & + \\
\hline 18 & Cellobiose & + \\
\hline 19 & + & + \\
\hline
\end{tabular}

*-Strain variation; ND- No data available in database when calculating percentage similarity.

\section{Discussion}

Two bacterial isolates Steptococcus sp. Pseudomonas sp. PDB $11(40.37 \%)$ and PDB $11(58.62 \%)$ were showed significant phenol degradation efficiency after $96 \mathrm{~h}$ under un-optimized condition (Table 1). Bacterial strains PDB 5 (74.67\%) and Pseudomonas sp. PDB $11(81.51 \%)$ showed significant phenol degradation efficiency after $96 \mathrm{~h}$ under optimized condition. Therefore after optimization phenol degradation rate increased by 1.84 fold for PDB 5 (from $40.37 \%$ to $74.67 \%$ ), 1.39 fold for PDB 11 (from 58.62\% to $81.51 \%$ ) shown in Table 3. Streptococcus sp. PDB 5 and Pseudomonas sp. PDB 11 were identified as potential phenol degrading bacterial strains.

Table 6: Identification of bacterial isolates based on Morphological and Biochemical characteristics as per described in Bergey's Manual

\begin{tabular}{|l|l|l|l|}
\hline S.N. & $\begin{array}{l}\text { Bacterial } \\
\text { Isolates }\end{array}$ & $\begin{array}{l}\text { Identified (as per } \\
\text { Bergey's Manual) }\end{array}$ & $\begin{array}{l}\text { Percentage } \\
\text { similarity }\end{array}$ \\
\hline 1 & $\begin{array}{l}\text { Streptococcus } \\
\text { sp. PDB 5 }\end{array}$ & $\begin{array}{l}\text { Streptococcus } \\
\text { epidermis }\end{array}$ & $93 \%$ \\
\hline 2 & $\begin{array}{l}\text { Pseudomonas } \\
\text { sp. PDB 11 }\end{array}$ & $\begin{array}{l}\text { Psuedomonas } \\
\text { aeruginosa }\end{array}$ & $91 \%$ \\
\hline
\end{tabular}

Several studies have been reported with the pure culture of Pseudomonas sp. (Pseudomonas putida and P. aeruginosa) (Allsop et al., 1993; Ahmed, 1995; Annadurai et al., 2002; Chao et al., 2007) in which, phenols degraded via metapathway (Carme et al., 1987). In 2009, Chakraborty et al., were studied on biodegradation of phenol by native microorganisms isolated from coke processing wastewater and observed that maximum degradation of $33.46 \%$ occurred at $30^{\circ} \mathrm{C}$ after $6 \mathrm{~h}$ and at the end of $24 \mathrm{~h}\left(30^{\circ} \mathrm{C}\right)$ $76.69 \%$ of phenol degradation was recorded. Further, Chandana et al., (2011) revealed that the concentration of $0.2 \mathrm{~g} / 1$ ammonium chloride in media enhanced phenol degradation rate up to $73.28 \%$ with Pseudomonas aeruginosa. Pandimadevi et al., (2014) optimized the concentration of media ingredients (Phenol, $\mathrm{K}_{2} \mathrm{HPO}_{4}$, $\mathrm{KH}_{2} \mathrm{PO}_{4}, \mathrm{MgSO}_{4},\left(\mathrm{NH}_{4}\right) 2 \mathrm{SO}_{4}, \mathrm{MnSO}_{4}, \mathrm{FeSO}_{4}, \mathrm{NaCl}$ and $\mathrm{H}_{3} \mathrm{BO}_{3}$ ) to enhance the rate of phenol degradation by $P$. aeruginosa (MTCC 7814). They optimized the concentration of media ingredients by Central composite Design (CCD) and Response Surface Methodology (RSM) and the observation revealed the optimal values of ingredients were $\mathrm{KH}_{2} \mathrm{PO}_{4} 0.025 \mathrm{~g} / 1,\left(\mathrm{NH}_{4}\right) 2 \mathrm{SO}_{4} 0.45 \mathrm{~g} / \mathrm{l}$, $\mathrm{MnSO}_{4} 0.05 \mathrm{~g} / \mathrm{l}$ and phenol $1000 \mathrm{mg} / \mathrm{l}$ with maximum rate of phenol degradation $(83.86 \%)$. In 2006 , September, $9^{\text {th }}$ International Conference on Environmental Science and Technology held on Rhodes Island, Greece where Wang et al., revealed that in their experiment Streptococcus showed maximum phenol degradation rate at $\mathrm{pH} 6.5$ and temperature $32^{\circ} \mathrm{C}$. Later (2010) Mohite et al., revealed that Streptococcus epidermis isolated from soil was able to degrade $200 \mathrm{mg} / \mathrm{l}$ of phenol and confirmed by both spectrophotometric and HPLC analysis. In 2015 Mohite again conducted the study on biotransformation of phenol and its derivatives and found that 4-nitrophenol was best transformed by Streptococcus epidermis at $\mathrm{pH} 7.0$ and temperature $32^{\circ} \mathrm{C}$. 


\section{Conclusion}

The present research was focused on the isolation and media optimization for phenol degrading bacterial strains. Streptococcus sp. PDB 5 and Streptococcus sp. PDB 11 were identified as potential phenol degrading bacterial strains. These bacterial strains would be effectively applied on microbially assisted phenol degradation of industrial wastewater which consisted of excess phenolic compounds. Further mutagenesis and kinetic study will be applied on Streptococcus sp. PDB 5 and Streptococcus sp. PDB 11 to enhance their phenol degrading efficiency at higher phenol concentration $(\leq 500 \mathrm{mg} / 1)$.

\section{References}

Agarry SE, Durojaiye AO and Solomon BO (2008) Microbial degradation of phenols: a review. Int. J. Environ. Pollut. 32(1): 12-28. DOI: 10.1504/IJEP.2008.016895

Ahmed AM (1995) Phenol Degradation by Pseudomonas aeruginosa. J. Environ. Sc. Health. 30: 99-103.

Allsop PJ, Chisti Y, Moo-Young M and Sullivan GR (1993) Dynamics of phenol degradation by Pseudomonas putida, Biotechnol. Bioeng. 41 (5): 572-580. DOI: 10.1002/bit.260410510

Annadurai G, Juang RS and Lee DJ (2002) Microbiological degradation of phenol using mixed liquors of Pseudomonas putida and activated sludge. Waste Manage. 22: 703-710. DOI: 10.1016/S0956053X(02)00050-8

Carme M, Maite N and Albert B (1987) Selection and adaptation of a phenol degrading strain of Pseudomonas. Biotechnol. Lett. 9: 655-660. DOI: 10.1007/BF01033206

Chakraborty S, Bhattacharya T, Patel TN and Tiwari KK (2010) Biodegradation of phenol by native microorganisms isolated from coke processing wastewater. Journal of Environmental Biology 293296.

Chandana Lakshmi MVV, Sridevi V, Narasimha Rao M, Swamy AVN (2011) Optimization of phenol degradation from Pseudomonas aeruginosa (NCIM 2074) using Response Surface Methodology. International Journal of Research In Pharmacy And Chemistry 1(4): 925-935

Chao W and $\mathrm{Yi} \mathrm{Li} \mathrm{(2007)} \mathrm{Incorporation} \mathrm{of} \mathrm{granular}$ activated carbon in an immobilized membrane bioreactor for the biodegradation of phenol by Pseudomonas putida. Biotechnol. Lett. 29: 13531356. DOI: $10.1007 / \mathrm{s} 10529-007-9405-7$

Dagley S (1971) Catabolism of aromatic compounds by micro-organisms. Adv. Microb. Physiol. 6: 1-46. DOI: $10.1016 /$ S0065-2911(08)60066-1
El-Ashtoukhy E, El-Taweel Y, Abdelwahab O and Nassef E (2013) Treatment of petrochemical wastewater containing phenolic compounds by electrocoagulation using a fixed bed electrochemical reactor. Int. J. Electrochem. Sci. 8: 1534-1550.

Greenberg AE, Clesceri LS and Eaton AD (1992) Standard Methods for the Examination of Water and Wastewater, American Public Health Association, American Water works Association, Water Environmental Federation.

Jadhav D and Vanjara A (2004) Removal of phenol from wastewater using sawdust, polymerized sawdust and sawdust carbon. Indian J. Chem. Tech. 11(1): 35-41.

Lin SH and Chuang TS (1994) Combined treatment of phenolic wastewater by wet air oxidation and activated sludge. Toxicol. Environ. Chem. 44: 243258. DOI: $10.1080 / 02772249409358063$

Mohite BV (2015) Efficient Biotransformation of Phenol and its Derivatives using Streptococcus epidermis by Catechol 2,3-Dioxygenase Metabolism. Environmental Engineering and Management Journal. 14(4): 843-849.

Mohite BV, Jalgaonwala RE, Pawar S and Morankar A (2010) Isolation and characterization of phenoldegrading bacteria from oil contaminated soil. Innov. Romanian Food Biotech. 7: 61-65.

Paisio CE Talano MA González PS Pajuelo-Domínguez E Agostini E (2013) Characterization of a phenoldegrading bacterium isolated from an industrial effluent and its potential application for bioremediation. Environ. Tech. 34(4): 485- 493. DOI: $10.1080 / 09593330.2012 .701238$

Pandimadevi M, Prabhu V, Kumar M and Vinod V (2014) Optimization of Phenol Degradation Using Pseudomonas aeruginosa (MTCC 7814) by Plackett-Burman Design and Response Surface Methodology. J. Bioremed. Biodeg. 5: 261.

Sa CSA and Boaventura RAR (2001) Biodegradation of phenol by Pseudomonas putida DSM 548 in a trickling bed reactor. Biochem. Eng. J. 9: 21. DOI: 10.1016/S1369-703X(01)00149-8

Shingler V (1996) Molecular and regulatory checkpoints in phenol degradation by Pseudomonas sp. CP600. In: Nakazawa, T, Furukawa K, Haas D and Silver S (eds.) Molecular biology of Pseudomonads. Am. Soc. Micorbiol. 153-164.

Sivasubramanian S and Namasivayam SKR (2014) Phenol degradation using Candida tropicalis SSK01 isolated from petroleum contaminated soil under optimized medium. J. Pure Appl. Microbiol. 8(1): 641-650. 
Veeresh GS, Kumar P and Mehrotra I (2005) Treatment of phenol and cresols in upflow anaerobic sludge blanket (UASB) process: a review. Water Res. 39(1): 154-170. DOI: 10.1016/j.watres.2004.07.028

Wang Q, Peisheng MA, Naiji WU and Qingzhu JIA (2006) Kinetics of Phenol Degradation by Streptococcus. Proceedings of the 9th International Conference on Environmental Science and Technology Rhodes island, Greece, 1-3 September.

Wang SJ and Loh KC (1999) Modeling the role of metabolic intermediates in kinetics of phenol biodegradation. Enzyme Microb. Technol. 25(3-5) 177-184. DOI: 10.1016/S0141-0229(99)00060-5

Yuan SY, Wei SH and Chang BV (2000) Biodegradation of polycyclic aromatic hydrocarbons by a mixed culture. Chemosphere 41(9): 1463-1468. DOI: 10.1016/S00456535(99)00522-6

Zilli M, Converti A, Lodi A, Borghi MD and Ferraiolo G (1993) Phenol removal from waste gases with a biological filter by Pseudomonas putida. Biotechnol. Bioeng. 41: 693-699. DOI: 10.1002/bit.260410703 